\title{
Effect of the dietary level of cull pinto beans (Phaseolus vulgaris) on ruminal fermentation, kinetics, and digestibility of hair lambs
}

\author{
Francisco Castillo Rangel ${ }^{1}$, Guillermo Villalobos Villalobos ${ }^{1 *}$, David Domínguez Díaz ${ }^{1}$, Juan \\ Ángel Ortega Gutiérrez ${ }^{1}$
}

\footnotetext{
${ }^{1}$ Universidad Autónoma de Chihuahua, Facultad de Zootecnia y Ecología, Chihuahua, Chihuahua, México.
}

\begin{abstract}
The objective was to evaluate the effect of three levels of cull pinto beans (CPB; Phaseolus vulgaris) on ruminal fermentation, kinetics, and nutrient digestibility in hair lambs. Six cannulated lambs averaging $56.6 \pm 3.8 \mathrm{~kg}$ were used and were randomly assigned to one of three treatments. Treatments were: $0.0 \mathrm{~kg} \mathrm{~kg}^{-1}$ of CPB in the supplement (control); $0.25 \mathrm{~kg} \mathrm{~kg}^{-1}$ of CPB in the supplement (CB25); and $0.40 \mathrm{~kg} \mathrm{~kg}^{-1}$ of CPB in the supplement (CB40). Dry matter intake, ruminal $\mathrm{pH}, \mathrm{NH}_{3}$, and volatile fatty acid (VFA) concentration, methane production, Kp (passage rate), MRT (mean retention time), and digestibility of dry matter, crude protein, and neutral detergent fiber were evaluated. Data were analyzed in a Latin square design, repeated in line, by MIXED procedure of SAS. Estimates used for Kp and MRT were obtained by a non-linear regression model (PROC NLIN). Dry matter intake was reduced by supplementation of CPB. No differences were found in ruminal $\mathrm{pH}$ or ruminal $\mathrm{NH}_{3}$. During the trial, differences were found for ruminal VFA concentration ( $\mathrm{mM}$ ), which were greater for the CB25 group. The propionate:acetate ratio was greater for the CB40 treatment. Methane production (mM/m) differed among treatments, but it was the greatest for the CB40 group. Passage rate $\left(\mathrm{kg} \mathrm{kg}^{-1} / \mathrm{h}\right)$ and MRT (h) were similar among treatments and the digestibility $\left(\mathrm{kg} \mathrm{kg}^{-1}\right)$ of dry matter, crude protein, and neutral detergent fiber was not different among treatments. The inclusion of $0.25 \mathrm{~kg} \mathrm{~kg}^{-1}$ of CPB in the diet of hair lambs allows for appropriate nutrient digestion without affecting Kp and MRT and increases the molar proportion of the ability of VFA to maintain acetate:propionate ratio without increasing methane production.
\end{abstract}

Key Words: ammonia, legumes, methane, ruminal $\mathrm{pH}$, sheep, volatile fatty acids

\section{Introduction}

In the last decade, the price of cereal grains and proteic ingredients has increased due to ethanol production. Substitutes for these types of feeds have become a priority for producers (Ramos et al., 2009) and agricultural byproducts represent an alternative in animal feeding. Cull pinto beans (CPB; Phaseolus vulgaris) are an ingredient used for ovine feeding in Mexico when they do not meet the quality standards necessary for human consumption. Cull pinto beans represent a good source of protein, vitamins, minerals, and complex carbohydrates. Their effect on animal

Received: June 2, 2016

Accepted: November 6, 2016

*Corresponding author: gvilla@uach.mx

http://dx.doi.org/10.1590/S1806-92902017000500006

How to cite: Castillo Rangel, F.; Villalobos Villalobos, G.; Domínguez Díaz, D. and Ortega Gutiérrez, J. A. 2017. Effect of the dietary level of cull pinto beans (Phaseolus vulgaris) on ruminal fermentation, kinetics, and digestibility of hair lambs. Revista Brasileira de Zootecnia 46(5):405-412.

Copyright (C) 2017 Sociedade Brasileira de Zootecnia. This is an Open Access article distributed under the terms of the Creative Commons Attribution License (http://creativecommons.org/licenses/by/4.0/), which permits unrestricted use, distribution, and reproduction in any medium, provided the original work is properly cited. performance has also been well studied. Villalobos et al. (2010a) reported that, as dietary intake of CPB increased, average daily gain (ADG) decreased. In another study, Castillo et al. (2011) reported a reduction in dry matter intake (DMI) when CPB was present as a supplement for pregnant-lactating hair ewes. However, its effect on ruminal fermentation and kinetics has not previously been studied. Because of its nutritive characteristics, high oligosaccharide content $\left(0.004 \mathrm{~kg} \mathrm{~kg}^{-1}\right.$ of raffinose, $0.0323 \mathrm{~kg} \mathrm{~kg}^{-1}$ of stachyose, and $0.0012 \mathrm{~kg} \mathrm{~kg}^{-1}$ of verbascose of DM (Serrano and Goñi, 2004)), and the presence of anti-nutritional factors (lectins, protease inhibitor factor, tannins, saponins, etc.) (Mejía et al., 2003), it was hypothesized that its inclusion in the diet of lambs will affect the ruminal fermentation and kinetics of hair lambs.

The objective of this study was to evaluate the effect of three levels of $\mathrm{CPB}$ on feed intake, ruminal fermentation, nutrient digestibility, and ruminal kinetics in hair lambs. The present investigation contributes to the knowledge and development of effective feeding strategies for sheep producers with $\mathrm{CPB}$ and will help advance the understanding of how this ingredient affects fermentation patterns and ruminal kinetics in ovine. 


\section{Material and Methods}

All procedures involving animals followed the local official techniques for animal care and were approved by the relative authorities (NOM-051-ZOO-1995: Humanitarian care of animals during mobilization of animals; NOM-024-ZOO-1995: Animal health stipulations and characteristics during transportation of animals). This study was conducted in Chihuahua City, Chihuahua, Mexico (28 $35^{\prime} 09^{\prime \prime} \mathrm{N}$ and $\left.106^{\circ} 06^{\prime} 27^{\prime \prime} \mathrm{W}\right)$.

Six crossbred (Dorper $\times$ Pelibuey and Charolais $\times$ Pelibuey), rumen-fistulated wethers, averaging 56.6 \pm 3.8 $\mathrm{kg}$, were used. At the start of the experiment, all wethers were identified, vaccinated with a three-way clostridial vaccine (Bacterina triple bovina, Bio- ZOO S. A. de C. V., Zapopan, Jalisco, Mexico), treated for external and internal parasites with ivermectin (Iverfull, Aranda Salud Animal, Querétaro, Querétaro, México), and given ADE vitamins. During the experiment, wethers were separated in individual cages and fed ad libitum (08.00 and $18.00 \mathrm{~h}$ ). Diets were mixed once and consisted of $0.50 \mathrm{~kg} \mathrm{~kg}^{-1}$ alfalfa hay and $0.50 \mathrm{~kg} \mathrm{~kg}^{-1}$ concentrate based on ground sorghum grain and were formulated to contain $0.218 \mathrm{~kg} \mathrm{~kg}^{-1}$ crude protein (CP) and $2.8 \mathrm{Mcal}$ of metabolizable energy (ME)/kg of dry matter (DM) (Table 1). Animals were allowed free access to water. Wethers were randomly assigned to one of the three treatments. Within second treatment, animals were randomly assigned to one of six cages. Treatments consisted of (DM basis): no CPB (control); $0.25 \mathrm{~kg} \mathrm{~kg}^{-1} \mathrm{CPB}$ (CB25); and $0.40 \mathrm{~kg} \mathrm{~kg}^{-1} \mathrm{CPB}$ (CB40) in the supplement, with CPB replacing ground sorghum grain, cottonseed meal, and

Table 1 - Ingredients and chemical composition (dry matter basis) of concentrate diets for hair lambs fed cull pinto beans

\begin{tabular}{lccc}
\hline \multirow{2}{*}{ Item } & \multicolumn{3}{c}{ Treaatment $^{1}$} \\
\cline { 2 - 4 } & Control & CB25 & CB40 \\
\hline Ingredient $\left(\mathrm{kg} \mathrm{kg}^{-1}\right)$ & & & \\
Cull pinto beans & 0.0 & 0.266 & 0.436 \\
$\quad$ Ground sorghum & 0.347 & 0.176 & 0.283 \\
Corn dried distillers' grains & 0.472 & 0.443 & 0.062 \\
Cottonseed meal & 0.157 & 0.091 & 0.195 \\
Salt & 0.012 & 0.012 & 0.012 \\
Microfos 12:10 & 0.012 & 0.012 & 0.012 \\
Calculated chemical composition & & & \\
(kg kg-1 dry matter basis) & & & \\
Crude protein & 0.218 & 0.218 & 0.218 \\
Metabolizable energy (Mcal $/ \mathrm{kg})$ & 2.8 & 2.8 & 2.8 \\
Ca & 0.0025 & 0.0023 & 0.0022 \\
P & 0.0065 & 0.0051 & 0.0051 \\
\hline
\end{tabular}

Control - $0.0 \mathrm{~kg} \mathrm{~kg}^{-1}$ of cull pinto beans of the supplement; CB25-0.25 kg kg-1 of cull pinto beans of the supplement; CB40 - $0.40 \mathrm{~kg} \mathrm{~kg}^{-1}$ of cull pinto beans of the supplement.

${ }^{2}$ Microfos 12:10: P, $0.12 \mathrm{~kg} \mathrm{~kg}^{-1} ; \mathrm{Ca}, 0.115 \mathrm{~kg} \mathrm{~kg}^{-1} ; \mathrm{Mg}, 0.006 \mathrm{~kg} \mathrm{~kg}^{-1} ; \mathrm{Mn}, 2160 \mathrm{mg} \mathrm{kg}^{-1}$; $\mathrm{Zn}, 2850 \mathrm{mg} \mathrm{kg}^{-1} ; \mathrm{Fe}, 580 \mathrm{mg} \mathrm{kg}^{-1}$; Cu, $1100 \mathrm{mg} \mathrm{kg}^{-1} ; \mathrm{I}, 102 \mathrm{mg} \mathrm{kg}^{-1} ; \mathrm{Co}, 13 \mathrm{mg} \mathrm{kg}^{-1}$; Se, $9 \mathrm{mg} \mathrm{kg}^{-1}$; vitamin A, 22,000 $\mathrm{IU} \mathrm{kg}^{-1}$; vitamin E, 24,500 $\mathrm{IU} \mathrm{kg}^{-1}$. corn dried distillers' grains. During each period, animals received nine days to adapt to their diets.

Dry matter intake was evaluated daily during the sampling period (seven days). During the first day of the sampling period (day 10 of each period), a ruminal fluid sample $(200 \mathrm{~mL})$ was obtained $(0,1,2,4,8,12,18$, $24 \mathrm{~h}$ after morning feeding). In the ruminal fluid sample, ruminal $\mathrm{pH}$ was measured immediately (UltraBASIC $\mathrm{pH} / \mathrm{mV}$ Meter; Denver Instrument) and four subsamples (15 mL) of strained fluid were taken and acidified with $0.2 \mathrm{~mL}$ of sulfuric acid $\left(50 \mathrm{~kg} \mathrm{~kg}^{-1}\right)$, then frozen until laboratory analysis. Samples were later thawed in the refrigerator $\left(12 \mathrm{~h}\right.$ at $\left.4{ }^{\circ} \mathrm{C}\right)$, then centrifuged at $13800 \times \mathrm{g}$ for $20 \mathrm{~min}$, and supernatant fraction was analyzed for $\mathrm{NH}_{3} \mathrm{~N}$ (Broderick and Kang, 1980). Volatile fatty acid (VFA; acetate, propionate, and butyrate) samples were prepared by centrifuging the sample at $10,000 \times g$ for $10 \mathrm{~min}$ at $4{ }^{\circ} \mathrm{C}$. Supernatant fraction was filtered twice and three subsamples were prepared with meta-phosphoric acid $(5 \mathrm{~mL}$ of sample and $1 \mathrm{~mL}$ of meta-phosphoric acid), according to Galyean (1980). Volatile fatty acids were analyzed with a Varian capillary column CP-wax 58 (FFAP) $(15 \mathrm{~m} \times 0.53 \mathrm{~mm}, 0.5 \mu \mathrm{m})$ by gas chromatography. Methane production was estimated according to the method proposed by Wolin (1960).

To analyze ruminal kinetics, $1 \mathrm{~g}$ of chromic oxide ( $0.99 \mathrm{~kg} \mathrm{~kg}^{-1}$ of purity) was administered to each lamb in the second day $(08.00 \mathrm{~h})$ of the sampling period to evaluate passage rate $(\mathrm{Kp})$ and mean retention time (MRT). Fecal samples $(30 \mathrm{~g})$ were obtained during six days (at 0,8 , $12,16,20,24,28,32,36,42,48,54,60,72,84,96$, $108,120,132,144 \mathrm{~h}$ ) and frozen until laboratory analysis. Samples were dried in a forced-air oven $\left(60^{\circ} \mathrm{C}\right)$ for five days, then were ground in a Wiley mill through a $1-\mathrm{mm}$ screen (Wiley mill model 4, Thomas Scientific, Swedesboro, NJ), and then incinerated $\left(8 \mathrm{~h}\right.$ at $\left.600{ }^{\circ} \mathrm{C}\right)$. After that, samples were processed according to the method described by Williams et al. (1962) and $\mathrm{Cr}$ concentration was obtained by atomic absorption spectrophotometry (Atomic Absorption Spectrophotometer, Analyst 200, Perkin Elmer Instruments; Lumina Lamp, Perkin Elmer).

For digestibility of dry matter, crude protein, and neutral detergent fiber (NDF), fecal samples were taken directly from the rectum of the animals four times daily as follows: day $1,08.00,10.00,12.00$, and $14.00 \mathrm{~h}$; day 2 , $16.00,18.00,20.00$, and $22.00 \mathrm{~h}$; and day 3,00.00, 02.00, 04.00 , and 06.00; in the first three days of the sampling period (days 10, 11, and 12 of each period). Individual fecal samples consisted of approximately $50 \mathrm{~g}$ (wet basis). Samples for each animal were composited for analysis and stored at $-20^{\circ} \mathrm{C}$. Composited fecal samples were dried 
in a forced-air oven $\left(60{ }^{\circ} \mathrm{C}\right)$ for five days. Feed, orts, and fecal samples were ground in a Wiley mill through a $1-\mathrm{mm}$ screen and analyzed for CP (method 976.05; AOAC, 2003). Acid detergent fiber (ADF) and NDF were determined sequentially according to Van Soest et al. (1991) using an Ankom 200 fiber analyzer (Ankom Technology, Fairport, NY). Feed and fecal samples were incubated (DAISYII system; Ankom Technology Corp. Fairport, NY) during five days (Mabjeesh et al., 2000). After incubation, bags were washed four times with cold water for $5 \mathrm{~min}$ and then dried $\left(60{ }^{\circ} \mathrm{C}\right)$ for $24 \mathrm{~h}$. Concentration of ADF was determined in the bag residue to calculate the percentage of indigestible ADF (Penning and Johnson, 1983).

Apparent dry matter digestibility was predicted using insoluble ADF according to the following formula (Schneider and Flatt, 1975):

\section{DMD kg kg-1 $=\left(100-\left(100 \times\left(\mathrm{kg} \mathrm{kg}^{-1}\right.\right.\right.$ IADF in feed $/ \mathrm{kg} \mathrm{kg}^{-1}$ IADF in feces)) )}

Apparent digestibility of $\mathrm{CP}$ and NDF were calculated using the following formula: $\mathrm{ND}=\left(100-\left(100 \times\left(\left(\mathrm{kg} \mathrm{kg}^{-1}\right.\right.\right.\right.$ IADF in feed $/ \mathrm{kg} \mathrm{kg}^{-1}$ IADF in feces $) \times\left(\mathrm{kg} \mathrm{kg}^{-1}\right.$ of nutrient in feces $/ \mathrm{kg} \mathrm{kg}^{-1}$ of nutrient in feed)))), in which DMD = digestibility of dry matter; IADF $=$ indigestible acid detergent fiber; and $\mathrm{ND}=$ nutrient digestibility.

Data for DMI, ruminal $\mathrm{pH}$, ammonia, and VFA concentration; methane production, and digestibility of DM (DMD), CP (CPD), and NDF (NDFD) were analyzed with the MIXED procedure of SAS (Statistical Analysis System, version 9.1.3) in a $3 \times 3$ Latin square design, repeated in line. Model statement included the effect of treatment, period, animal, and hour (except for DMI, DMD, CPD, and NDFD) and the interaction treatment $\times$ hour.

The mathematical model used was:

$$
\mathrm{y}_{\mathrm{ijklm}}=\mu+\tau_{\mathrm{i}}+\rho_{\mathrm{j}}+\sigma_{\mathrm{k}}+\mathrm{o}_{1}+\Theta_{\mathrm{il}}+\mathrm{a}_{\mathrm{m}}\left(\sigma_{\mathrm{k}}\right)+\mathrm{e}_{\mathrm{ijklm}},
$$

in which $\mathrm{y}_{\mathrm{ijklm}}=$ observed value of the variable that received the level of CPB $i$, period $\mathrm{j}$, repetition $\mathrm{k}$, hour $\mathrm{l}$, and animal $\mathrm{m}$; $\mu=$ overall mean; $\tau_{\mathrm{i}}=$ dietary level of $\mathrm{CPB}$ effect; $\rho_{\mathrm{j}}=$ period effect; $\sigma_{k}=$ Latin square repetition effect; $o_{1}=$ hour effect; $\Theta_{\mathrm{il}}=$ interaction between level of CPB and hour; $\mathrm{a}_{\mathrm{m}}\left(\sigma_{\mathrm{k}}\right)=$ animal within Latin square repetition; and $\mathrm{e}_{\mathrm{ijklm}}=$ random error associated with each observation.

To evaluate the concentration of $\mathrm{Cr}$ in feces, a non-linear regression model proposed by Pond et al. (1987) was used: $\mathrm{Cr}$ concentration $=((\mathrm{K} 0 \times \mathrm{L} 1 \times \mathrm{T}) \times(\mathrm{EXP}(-\mathrm{L} 1 \mathrm{~T}))) / 0.59635$, in which $\mathrm{K} 0=$ concentration of marker if instantaneously mixed in the compartment; L1 = age-dependent rate parameter; and $\mathrm{T}=$ time after marker administration.

Data were analyzed by NLIN procedure of SAS to obtain the non-linear model estimates for each animal within treatment. The data obtained were analyzed by
ANOVA to understand the effect of CPB inclusion level on $\mathrm{Kp}$ and MRT in a $3 \times 3$ Latin square design, repeated in line. Data were analyzed by MIXED procedure of SAS. When significant $(\mathrm{P}<0.05), \mathrm{F}$-statistics were noted and the means separated using linear and quadratic contrast.

The mathematical model used was:

$$
\mathrm{y}_{\mathrm{i} j \mathrm{kl}}=\mu+\tau_{\mathrm{i}}+\rho_{\mathrm{j}}+\sigma_{\mathrm{k}}+\mathrm{a}_{\mathrm{l}}\left(\sigma_{\mathrm{k}}\right)+\mathrm{e}_{\mathrm{ij} \mathrm{kl}} \text {, }
$$

in which $\mathrm{y}_{\mathrm{ijk}}=$ observed value of the variable that received the level of CPB $i$, period $\mathrm{j}$, repetition $\mathrm{k}$, animal $1 ; \mu=$ overall mean; $\tau_{\mathrm{i}}=$ dietary level of CPB effect; $\rho_{\mathrm{j}}=$ period effect; $\sigma_{\mathrm{k}}=$ Latin square repetition effect; $\mathrm{a}_{\mathrm{l}}\left(\sigma_{\mathrm{k}}\right)=$ animal within Latin square repetition; and $\mathrm{e}_{\mathrm{ijkl}}=$ random error associated with each observation.

\section{Results and Discussion}

Dry matter intake was greater $(\mathrm{P}>0.05)$ for the control group (control: 1.77 \pm 0.08 ; CB25: $1.62 \pm 0.08$; CB40: $1.62 \pm 0.08)$. Data for ruminal $\mathrm{pH}$ and ruminal $\mathrm{NH}_{3} \mathrm{~N}$ concentration did not differ $(\mathrm{P}>0.05)$ among treatments (Table 2). Treatment $\times$ hour interaction was found $(\mathrm{P}<0.05)$ for VFA, acetic, propionic, and butyric acid concentrations (Table 3$)$. When feed was offered $(0 \mathrm{~h})$, total VFA concentration was greater $(\mathrm{P}<0.01)$ for $\mathrm{CB} 25$ group than for control and CB40 groups. However, in the first hour post feeding, VFA concentration of CB25 group increased and was greater $(\mathrm{P}<0.05)$ than VFA concentration of control and CB40 groups. During the trial, it was observed that total VFA concentration was greater $(\mathrm{P}<0.05)$ for $\mathrm{CB} 25$ group and acetic:propionic ratio was greater $(\mathrm{P}<0.01)$ for $\mathrm{CB} 40$ group. Acetic acid concentration was different $(\mathrm{P} \leq 0.01)$ when lambs were fed CPB and was greater for $\mathrm{CB} 25$ group. At 2 and $18 \mathrm{~h}$ post feeding, ruminal concentration of acetic acid was greater $(\mathrm{P}<0.05)$ for $\mathrm{CB} 40$ group. Average of acetic acid concentration during the complete period was greater $(\mathrm{P}<0.01)$ for those treatments that included $\mathrm{CPB}$ (Table 3). Data for propionic acid concentration showed

Table 2 - Effects of levels of cull pinto beans on ruminal $\mathrm{pH}$ and

\begin{tabular}{|c|c|c|c|c|c|}
\hline \multirow{2}{*}{ Item } & \multicolumn{3}{|c|}{ Treatment $^{1,2}$} & \multirow{2}{*}{$\mathrm{SE}$} & \multirow{2}{*}{ P-value } \\
\hline & Control & CB25 & CB40 & & \\
\hline \multicolumn{6}{|l|}{ Ruminal pH } \\
\hline Average & 6.19 & 6.23 & 6.19 & 0.07 & 0.3602 \\
\hline Lowest & 5.94 & 6.08 & 6.05 & 0.09 & 0.1673 \\
\hline Highest & 6.5 & 6.4 & 6.44 & 0.09 & 0.2455 \\
\hline $\mathrm{NH}_{3} \mathrm{~N}(\mathrm{mg} / 100 \mathrm{~mL})$ & 27.23 & 26.55 & 27.43 & 1.67 & 0.8324 \\
\hline
\end{tabular}
$\mathrm{NH}_{3} \mathrm{~N}$ concentration

${ }^{1}$ Control - $0.0 \mathrm{~kg} \mathrm{~kg}^{-1}$ of cull pinto beans in the supplement; CB25 - $0.25 \mathrm{~kg} \mathrm{~kg}^{-1}$ of cull pinto beans in the supplement; CB40 $-0.40 \mathrm{~kg} \mathrm{~kg}^{-1}$ of cull pinto beans in the supplement.

${ }^{2}$ No treatment $\times$ hour interaction was observed $(\mathrm{P}>0.05)$.

SE - standard error. 
that differences were found $(\mathrm{P}<0.05)$ at 0,12 , and $18 \mathrm{~h}$ and were greater for CB25 group during the test (Table 3). Butyric acid concentration was different $(\mathrm{P}<0.05)$ among treatments at $0,1,4,8$, and $18 \mathrm{~h}$, and during the trial (Table 3$)$. Differences $(\mathrm{P}<0.05)$ for methane production were found during the trial and were greater for CB40 group (Table 4). On the other hand, data for Kp (control: 3.6 \pm 1.9 ; CB25: 2.9 \pm 1.9 ; C40: 5.9 \pm 1.9 ) and MRT (control: 36.26 \pm 13.7 ; CB25: 57.68 \pm 13.7 ; C40: 36.24 \pm 13.7$)$ were not different $(\mathrm{P}>0.05)$ among treatments. Similarly to Kp and MRT, dry matter, crude protein, and neutral detergent fiber digestibilities $(\mathrm{P}>0.05)$ were not different among treatments (Table 5).

The effect of CPB inclusion on DMI varied because of different factors, such as age of the animal, physiological state, nutrient requirements, and quantity of $\mathrm{CPB}$ in the diet. Because of ad libitum feeding, as DMI increased, CPB intake increased. Paduano et al. (1995) reported that ovine can tolerate low anti-nutritional factor intake without having negative effects, while higher intake can decrease DMI, which is assumed to have occurred in the present study. Similar results to this study were found when feedlot

Table 3 - Least square means for volatile fatty acids $(\mathrm{mM} / \mathrm{L} ; \pm \mathrm{SE})$ of hair lambs supplemented with three levels of cull pinto beans

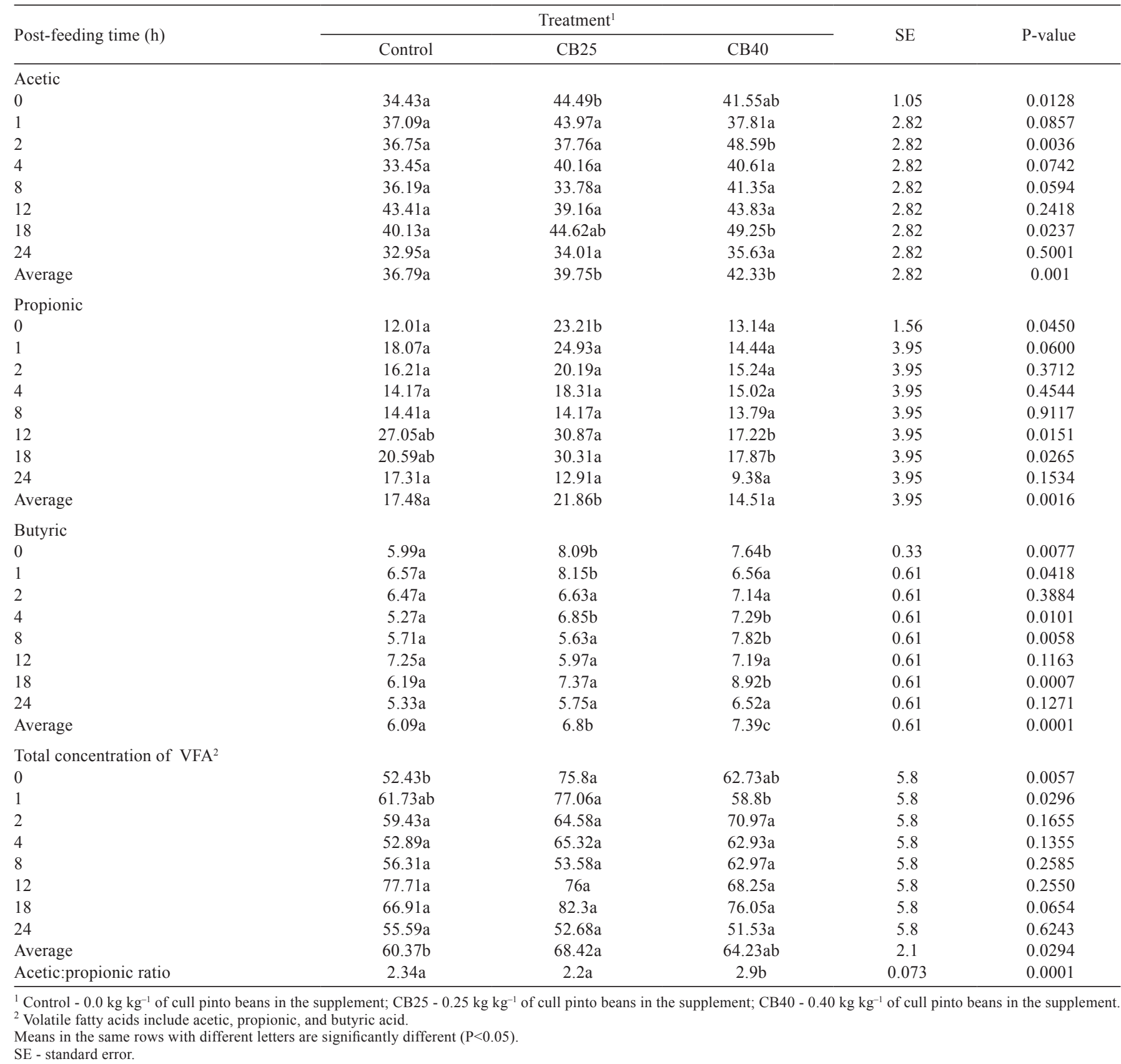


Table 4 - Least squares means $( \pm \mathrm{SE})$ for methane production $(\mathrm{mM} / \mathrm{mL})$ of hair lambs fed three different levels of cull pinto beans in the supplement during the day

\begin{tabular}{lccccc}
\hline \multirow{2}{*}{ Post-feeding time (h) } & \multicolumn{3}{c}{ Treatment $^{1}$} & & \\
\cline { 2 - 5 } & Control & CB25 & CB40 & & P-value \\
\hline 0 & $32.47 \mathrm{ab}$ & $28.02 \mathrm{~b}$ & $34.24 \mathrm{a}$ & 1.79 & 0.0139 \\
1 & $27.91 \mathrm{ab}$ & $25.88 \mathrm{~b}$ & $31.28 \mathrm{a}$ & 1.79 & 0.0319 \\
2 & $29.33 \mathrm{ab}$ & $26.44 \mathrm{~b}$ & $33.19 \mathrm{a}$ & 1.79 & 0.0077 \\
4 & $29.59 \mathrm{a}$ & $29.24 \mathrm{a}$ & $31.78 \mathrm{a}$ & 1.79 & 0.3084 \\
8 & $30.41 \mathrm{a}$ & $30.56 \mathrm{a}$ & $33.32 \mathrm{a}$ & 1.79 & 0.2438 \\
12 & $25.21 \mathrm{~b}$ & $22.78 \mathrm{~b}$ & $30.92 \mathrm{a}$ & 1.79 & 0.0015 \\
18 & $28.37 \mathrm{ab}$ & $25.42 \mathrm{~b}$ & $32.24 \mathrm{a}$ & 1.79 & 0.0072 \\
24 & $29.21 \mathrm{~b}$ & $32.38 \mathrm{ab}$ & $35.99 \mathrm{a}$ & 1.79 & 0.0074 \\
Average & $29.06 \mathrm{~b}$ & $27.59 \mathrm{~b}$ & $32.87 \mathrm{a}$ & 0.75 & 0.0001 \\
\hline
\end{tabular}

${ }^{1}$ Control - $0.0 \mathrm{~kg} \mathrm{~kg}^{-1}$ of cull pinto beans in the supplement; CB25- $0.25 \mathrm{~kg} \mathrm{~kg}^{-1}$ of cull pinto beans in the supplement; CB40 - $0.40 \mathrm{~kg} \mathrm{~kg}^{-1}$ of cull pinto beans in the supplement.

Means in the same rows with different letters are significantly different $(\mathrm{P}<0.05)$. $\mathrm{SE}$ - standard error.

Table 5 - Digestibility of nutrients $( \pm \mathrm{SE})$ of hair lambs fed three different levels of cull pinto beans

\begin{tabular}{lccccc}
\hline \multirow{2}{*}{ Item } & \multicolumn{3}{c}{ Treatment $^{1}$} & \multirow{2}{*}{ SE } & P-value \\
\cline { 2 - 4 } & Control & CB25 & CB40 & & \\
\hline DMD $\left(\mathrm{kg} \mathrm{kg}^{-1}\right)$ & 0.6897 & 0.6954 & 0.6938 & 0.0145 & 0.7617 \\
CPD $\left(\mathrm{kg} \mathrm{kg}^{-1}\right)$ & 0.7365 & 0.7381 & 0.7183 & 0.0158 & 0.3029 \\
NDFD $\left(\mathrm{kg} \mathrm{kg}^{-1}\right)$ & 0.4815 & 0.4863 & 0.4456 & 0.0207 & 0.2577 \\
\hline
\end{tabular}

${ }^{1}$ Control - $0.0 \mathrm{~kg} \mathrm{~kg}^{-1}$ of cull pinto beans in the supplement; CB25 - $0.25 \mathrm{~kg} \mathrm{~kg}^{-1}$ of cull pinto beans in the supplement; CB40 - $0.40 \mathrm{~kg} \mathrm{~kg}^{-1}$ of cull pinto beans in the supplement.

DMD - dry matter digestibility; CPD - crude protein digestibility; NDFD - neutral detergent fiber digestibility; SE - standard error.

lambs were fed different levels of CPB. Villalobos et al. (2010a) reported a quadratic effect with the greatest DMI in the control group. Among other factors affecting DMI, there was the chemical composition of the diet and digestibility; in this study, CB40 had the lowest NDF digestibility. Ruminants fed concentrates that contain legume grains can have an effect on DMI. However, Lardy et al. (2009) found different results in three experiments with finishing steers and heifers fed different levels of field peas in their diet. Such inconsistencies to when legume grains are fed to ruminants can be due to differences in the intake of antinutritional factors. As such, other authors have reported similar results (Encinias et al., 2000; Soto-Navarro et al., 2004) when field peas were fed to beef cattle.

For $\mathrm{pH}$, similar results were reported by Ramos et al. (2009), when $0.70 \mathrm{~kg} \mathrm{~kg}^{-1}$ of concentrate in the diet did not decrease ruminal $\mathrm{pH}$ from 6 . A reduction in ruminal $\mathrm{pH}$, however, can decrease fiber digestibility (Shriver et al., 1986) and, thus, a variation of ruminal $\mathrm{pH}$ during the day can negatively affect nutrient digestibility (Cerrato-Sánchez et al., 2007). The results of this study showed that ruminal $\mathrm{pH}$ did not affect DMD and NDF because it was similar across the day. Gilbery et al. (2007) reported that inclusion of field peas, lentil screenings, and chickpeas in feedlot cattle receiving diets did not affect ruminal $\mathrm{pH}$, with an average $\mathrm{pH}$ of 6.35 across the treatments that included these legume grains.

Performance of ammonia concentration across the day showed that crude protein degradation rate and solubility of $\mathrm{N}$ sources were not affected by CPB inclusion. Preliminary research (Castillo, 2011) has demonstrated that CPB is an ingredient that contains a desirable crude protein content $\left(0.21 \mathrm{~kg} \mathrm{~kg}^{-1}\right)$. The concentration of ammonia in the rumen is a function of both the rate of ruminal $\mathrm{N}$ degradation and the concentration of rumen degradable protein (RDP) above microbial needs and the amount of dietary energy available to the ruminal microorganisms (Hirstov et al., 2004). Increasing crude protein concentration or RDP percentage usually results in an increase of ruminal ammonia concentration (Armentano et al., 1993; Davidson et al., 2003). In the present study, supplements were isonitrogenous. Thus, it can be assumed that cull pinto bean ruminal degradation of the proteic fraction and RDP percentage are similar to those presented by the ingredients that were substituted by CPB. Similar results were presented by Singh et al. (2006), when cowpea grains were used in the diet of lambs. They found that the inclusion of this ingredient does not affect ruminal ammonia concentration; nonetheless, the results in this experiment are greater $\left(0.281 \mathrm{~kg} \mathrm{~kg}^{-1}\right)$ than those presented by those authors.

Volatile fatty acids are the main products of ruminal fermentation; thus, CPB inclusion allowed for improved ruminal fermentation in hair lambs. Because of the greater DMI of the control group, a greater ruminal VFA concentration was expected in this group; however, DMI did not affect the total VFA concentration. Similar results were found in the study of Reed et al. (2004), in which ruminal VFA concentration was not affected by the substitution of corn grain with field peas. Soto-Navarro et al. (2004) did not report differences on fermentative parameters when field pea levels increased. In another study, in which different legume grains were included in diets of feedlot beef cattle, it was reported that the presence of these ingredients decreased ruminal VFA concentration (Gilbery et al., 2007). Reed et al. (2004), however, reported that inclusion of field peas linearly decrease acetate molar proportion and do not have an effect on propionate and butyrate molar proportions. Contrary to the results presented in the present study, Gilbery et al. (2007) found that inclusion of legume grains decrease acetate concentration. Volatile fatty acid concentration is regulated by the balance between production and absorption. Van Soest (1994) found that proportions of VFA can vary with diet and that acetate is 
the major fatty acid produced in most of the conditions, supporting the findings of the present experiment.

Methanogenesis is an important terminal step in anaerobic fermentation within the rumen. Carbohydrates are the major energy source for microbes of the rumen and the production of methane is related to their fermentation. Currently, little information is available for methane production by ruminants fed agro-industrial byproducts and feeding strategies for ruminants, which achieve significant methane suppression, remain limited (Moss et al., 2000). Pelchen and Peters (1998) have reported that methane production is similar among ovine fed diets containing from 60 to $0.80 \mathrm{~kg} \mathrm{~kg}^{-1}$ of dry matter digestibility, although, when DMD was less than $0.60 \mathrm{~kg} \mathrm{~kg}^{-1}$, differences were found. In the present study, DMD in the diets averaged $0.69 \mathrm{~kg} \mathrm{~kg}^{-1}$ and did not differ significantly among treatments; nonetheless, differences for methane production were found during the trial and were greater for the CB40 group (Table 4). These differences could be due to the high level of CPB present, which, in turn, produced greater changes in ruminal fermentation compared with the ingredients already present in the concentrate because of the high oligosaccharide content of CPB. The rate of methane production is related to the production of hydrogen. Machmüller et al. (2003) found that methane production is similar throughout the day, it increases just after feeding, and is closely related to the fermentation rate. In the present study, methane production was similar during the day and it was associated with the ad libitum offer of feed.

The amount of feed consumed was probably the most important variable associated with retention time of digesta in the gastrointestinal tract of ruminant animals (Colucci et al., 1990). In ruminants, an increase in the amount of feed entering the gastrointestinal tract must be coupled with either an expansion of the organ or a faster rate of disappearance, which is related with digestibility or passage. During this experiment, it was noted that digestibility of dry matter was not different among treatments and DMI was similar between groups CB25 and CB40. Kp and MRT could be affected directly by both DMI and DMD; these processes depend directly on different factors such as density, particle size, starch content, protein content, and structural carbohydrates. The results of $\mathrm{Kp}$ and MRT could be associated with the physical and chemical characteristics of the feed, which, in the present study, were similar among treatments. Van Soest (1994) found that ruminal fermentation is a factor that can affect $\mathrm{Kp}$ and MRT. In this study, the similar ruminal fermentation $(\mathrm{pH}$ and $\mathrm{NH}_{3} \mathrm{~N}$ ) observed, can partially be explained by the fact that there were no differences in retention time of digesta in the gastrointestinal tract based on the level of CPB, leading to similar digestibility of nutrients among treatments.

For dry matter digestibility, differences were expected among the treatments, owing to the presence of antinutritional factors present in CPB. Villalobos et al. (2010b) reported different results when feedlot lambs were fed cull pinto beans. These differences could be due to the type of animal and the concentrate:forage ratio being different among experiments. The results in this experiment are supported by those of Williams et al. (1984) who fed pinto beans to steers. Nonetheless, other authors (Stanford et al., 1999; Singh et al., 2006) found that DMD decreased when the level of legume grains increased in the diets of lambs. The most important anti-nutritional factors in legume grains are usually lectins and protease-inhibitor factors (Paduano et al., 1995). These factors directly affect the digestion and absorption of nutrients that reduce animal performance. Williams et al. (1984) reported negative effects due to the presence of those anti-nutritional factors and Soto-Navarro et al. (2004) found that the inclusion of field peas in the diet of steers reduce forage in situ CP degradability. In the present study, it was assumed that physiological maturity of wethers allowed them to tolerate the presence of antinutritional factors. Preliminary research in ewes supports this. Castillo et al. (2011) demonstrated that mature ewes can tolerate higher levels of CPB than primiparous (averaging 11 months old), which developed diarrhea when $0.50 \mathrm{~kg} \mathrm{~kg}^{-1}$ of CPB was included in their supplement, while multiparous ewes (averaging 36 months old) did not develop this metabolic disorder. Other studies have reported similar results when different legume grains were fed to ruminants (Surra et al., 1992; Singh et al., 2006; Gilbery et al., 2007). Patterson et al. (1999) found that the inclusion of cull beans in the diets of steers decreased NDF degradability; these results are in contrast with those reported in this study. Fiber digestibility can be associated with different factors, such as ruminal $\mathrm{pH}$ and passage rate. It has also been well established that ruminal $\mathrm{pH}$ can affect fiber and protein digestibility (Hoover, 1986; Shriver et al., 1986). In the present study, it was observed that ruminal $\mathrm{pH}$ was similar among treatments and the passage rate was not different among treatments. These results, thus, explain the equal digestibility of NDF among treatments.

\section{Conclusions}

Cull pinto beans reduce dry matter intake, although they do not affect ruminal $\mathrm{pH}$ and $\mathrm{NH}_{3} \mathrm{~N}$ production. The inclusion of $0.25 \mathrm{~kg} \mathrm{~kg}^{-1}$ of cull pinto beans in the diet of hair lambs allows for appropriate nutrient digestibility 
without affecting passage rate and mean retention time and this increases the molar proportion of volatile fatty acids and maintains acetate to propionate ratio that also keeps methane production low. Our research indicates that cull pinto beans is a suitable substitute for a combination of ground sorghum, dry corn distiller grain, and cottonseed meal in concentrate diets of hair lambs.

\section{Acknowledgments}

Appreciation is expressed to Fundación Produce for its financial support.

\section{References}

AOAC - Association of Official Analytical Chemistry. 2003. Official methods of analysis. 17th ed. AOAC International, Arlington, VA.

Armentano, L. E.; Bertics, S. J. and Riesterer, J. 1993. Lack of response to addition of degradable protein to a low protein diet fed to midlactation dairy cows. Journal of Dairy Science 76:3755-3762.

Broderick, G. A. and Kang, J. H. 1980. Automated simultaneous determination of ammonia and total amino acids in ruminal fluids and in vitro media. Journal of Dairy Science 63:64-75.

Castillo, F. 2011. Uso de frijol de desecho en la alimentación de borregas de pelo en gestación - lactancia y engorda de corderos. Disertación (Ph. D.). Universidad Autónoma de Chihuahua, Chihuahua, Mexico.

Castillo, F.; Villalobos, G.; Domínguez, D.; Cruz, J. E.; Anchondo, A. and Ortega, J. A. 2011. Cull pinto bean as a supplement to pregnant-lactating hair ewes. Journal of Animal Science 89(ESuppl. 1):153.

Cerrato-Sánchez, M. S.; Calsamiglia, S. and Ferret, A. 2007. Effects of time and suboptimal $\mathrm{pH}$ on ruminal fermentation in a dual-flow continuous system. Journal of Dairy Science 90:1486-1492.

Colucci, P. E.; Macleod, G. K.; Grovum, W. L.; McMillan, I. and Barney, D. J. 1990. Digesta kinetics in sheep and cattle fed diets with different forage to concentrate ratios at high and low intakes. Journal of Dairy Science 73:2143-2156.

Davidson, S.; Hopkins, B. A.; Diaz, D. E.; Bolt, S. M.; Brownie, C.; Fellner, V. and Whitlow, W. 2003. Effects of amounts and degradability of dietary protein on lactation, nitrogen utilization, and excretion in early lactation Holstein cows. Journal of Dairy Science 86:1681-1689.

Encinias, A. M.; Scheaffer, A. N.; Radunz, A. E.; Bauer, M. L.; Lardy, G. P. and Caton, J. S. 2000. Influence of field pea supplementation on intake and performance of gestating beef cows fed grass hay diets. Canadian Journal of Animal Science 80:766-767 (Abstr).

Galyean, M. L. 1980. Laboratory procedures in animal nutrition research. Department on Animal and Food Sciences. Texas Tech University, Lubbock, TX, USA.

Gilbery, T. C.; Lardy, G. P.; Soto-Navarro, S. A.; Bauer, M. L. and Anderson, V. L. 2007. Effect of field peas, chickpeas, and lentils on rumen fermentation, digestion, microbial protein synthesis, and feedlot performance in receiving diets for beef cattle. Journal of Animal Science 85:3045-3053.

Hirstov, A. N.; Etter, R. P.; Ropp, J. K. and Grandeen, K. L. 2004. Effect of dietary crude protein level and degradability on ruminal fermentation and nitrogen utilization in lactating dairy cows. Journal of Animal Science 82:3219-3229.
Hoover, W. H. 1986. Chemical factors involved in ruminal fiber digestion. Journal of Dairy Science 69:2755-2766.

Lardy, G. P.; Loken, B. A.; Anderson, V. L.; Larson, D. M.; MaddockCarlin, K. R.; Ilse, B. R.; Maddock, R.; Leupp, J. L.; Clark, R.; Peterson, J. A. and Bauer, M. L. 2009. Effects of increasing field pea (Pisum sativum) level in high concentrate diets on growth performance and carcass traits in finishing steers and heifers. Journal of Animal Science 87:3335-3341.

Mabjeesh, S. J.; Cohen, M. and Arieli, A. 2000. In vitro methods for measuring the dry matter digestibility of ruminants feedstuffs: Comparison of methods and inoculums source. Journal of Dairy Science 83:2289-2294

Machmüller, A.; Soliva, C. R. and Kreuser, M. 2003. Methanesupressing effect of myristic acid in sheep as affected by dietary calcium and forage proportion. British Journal of Nutrition 90:529-540

Mejía, E. G.; Guzmán-Maldonado, S. H.; Acosta-Gallegos, J. A.; Reynoso-Camacho, R.; Ramírez-Rodríguez, E.; Pons-Hernández, J. L.; González-Chavira, M. M.; Castellanos, J. Z. and Kelly, J. D. 2003. Effect of cultivar and growing location on the tripsin inhibitors, tannins, and lectins of common beans (Phaseolus vulgaris L.) grown in semiarid highlands of Mexico. Journal of Agricultural and Food Chemistry 51:5962-5966.

Moss, A. R.; Jouany, J. P. and Newbold, J. 2000. Methane production by ruminants: its contribution to global warming. Annales de Zootechnie 49:231-253.

Norma Oficial Mexicana NOM-024-ZOO-1995, Especificaciones y características zoosanitarias para el transporte de animales, sus productos y subproductos, productos químicos, farmacéuticos, biológicos y alimenticios para uso en animales o consumo por éstos. Diario Oficial de la Federación, 16 de Octubre de 1995.

Norma Oficial Mexicana NOM-051-ZOO-1995, Norma oficial para trato humanitario en la movilización de animales. Diario Oficial de la Federación, 23 de Marzo de 1998.

Paduano, D. C.; Dixon, R. M.; Domingo, J. A. and Holmes, J. H. G. 1995. Lupin (Lupinus agustifolius), cowpea (Vigna unguiculata) and navy bean (Phaseolus vulgaris) seeds as supplements for sheep fed low quality roughage. Animal Feed Science and Technology 53:55-69.

Patterson, H. H.; Whittier, J. C. and Rittenhouse, L. R. 1999. Effect of cull beans, sunflower meal, and canola meal as protein supplement to beef steers consuming grass hay on in situ digestion kinetics. The Professional Animal Scientist 15:185-190.

Pelchen, A. and Peters, K. J. 1998. Methane emissions from sheep. Small Ruminant Research 27:137-150.

Penning, P. D. and Johnson, R. H. 1983. The use of internal markers to estimate herbage intake and digestibility. 1. Indigestible acid detergent fiber. Journal of Agricultural Science 100:133-138.

Pond, K. R.; Burns, J. C. and Fisher, D. S. 1987. External markers - use and methodology in grazing studies. p.49-53. In: Proceedings of the Grazing Livestock Nutrition Conference. Jackson, Wyoming, USA.

Ramos, S.; Tejido, M. L.; Martínez, M. E.; Ranilla, M. J. and Carro, M. D. 2009. Microbial protein synthesis, ruminal digestion, microbial populations, and nitrogen balance in sheep fed diets varying in forage to concentrate ratio and type of forage. Journal of Animal Science 87:2924-2934.

Reed, J. J.; Lardy, G. P.; Bauer, M. L.; Gilbery, T. C. and Caton, J. S. 2004. Effect of field pea level on intake, digestion, microbial efficiency, ruminal fermentation, and in situ disappearance in beef steers fed growing diets. Journal of Animal Science 82:2123-2130.

Schneider, B. H. and Flatt, W. P. 1975. Evaluation of feed trough digestibility experiments. University of Georgia Press, Athens, GA, USA. 
Serrano, J. and Goñi, I. 2004. Papel del frijol negro Phaseolus vulgaris en el estado nutricional de la población guatemalteca. Arch. Latinoam. Nutr. 54. Available at: < http://www.alanrevista.org/ ediciones/2004-1/frijol_negro_phaseolus_vulgaris.asp.>. Accessed on: Sept. 25, 2011.

Shriver, B. J.; Hoover, W. H.; Sargent, J. P.; Crawford, R. J. Jr. and Thayne, W. V. 1986. Fermentation of high concentrate diet as affected by ruminal $\mathrm{pH}$ and digesta flow. Journal of Dairy Science 69:413-419.

Singh, S.; Kundu, S. S.; Negi, A. S. and Singh, P. N. 2006. Cowpea (Vigna unguiculata) legume grains as protein source in the ration of growing sheep. Small Ruminant Research 64:247-254.

Soto-Navarro, S. A.; Williams, G. J.; Bauer, M. L.; Lardy, G. P.; Landblom, D. G. and Caton, J. S. 2004. Effect of field pea replacement level on intake and digestion in beef steers fed byproduct-based medium-concentrate diets. Journal of Animal Science 82:1855-1862.

Stanford, K.; Wallins, G. L.; Less, B. M. and Mündel, H. H. 1999. Use of lentil screenings in the diets of early weaned lambs and ewes in the second trimester of pregnancy. Animal Feed Science and Technology 81:249-264.

Surra, J.; Purroy, A.; Muñoz, F. and Treacher, T. 1992. Lentils and faba beans in lamb diets. Small Ruminant Research 7:43-49.
Van Soest, P. J.; Robertson, J. B. and Lewis, B. A. 1991 Methods for dietary fiber, neutral detergent fiber, and nonstarch polysaccharides in relation to animal nutrition. Journal of Dairy Science 74:3583-3589.

Van Soest, P. J. 1994. Nutritional ecology of the ruminants. 2nd ed. Cornell University Press, Ithaca, NY.

Villalobos, G.; Castillo, F.; Domínguez, D.; Castillo, H. and Ortega, J. A. 2010a. Use of waste pinto bean grain on finishing hair lambs. Proceedings of Western Section of American Society of Animal Science 61:293-296.

Villalobos, G.; Castillo, F.; Domínguez, D.; Ortega, J. A. and Carlos, L. 2010b. Consumo y digestibilidad de nutrientes en borregos de pelo en finalización alimentados con frijol de desecho. p.524-526. In: XX Reunión Internacional sobre Producción de Carne y Leche en Climas Cálidos. Mexicali, Baja California, México.

Williams, C. H.; David, D. J. and Iismaa, O. 1962. The determination of chromic oxide in feces samples by atomic absorption spechtrophotometry. Journal of Agricultural Science 59:381-385.

Williams, P. E. V.; Pustazi, A. J.; Macdearmid, A. and Innes, G. M. 1984. The use of kidney beans (Phaseolus vulgaris) as protein supplements in diets for young rapidly growing beef steers. Animal Feed Science and Technology 12:1-10.

Wolin, M. J. 1960. A theoretical rumen fermentation balance. Journal of Dairy Science 42:1452-1459. 